6. Гордієнко М.І. Чагарникові верби рівнинної частини України / М.І. Гордієнко, Я.Д. Фучило, А.Ф. Гойчук. - К. : Вид-во ІАЕ УААН, 2002. - 174 с.

7. Фучило Я.Д. Біологічні та технологічні основи плантаційного лісо вирощування / Я.Д. Фучило, М.І. Ониській, М.В. Сбитна. - К. : ННЦ "Ін. аграр. екон.", 2006. - 394 с.

Булат А.Г., Таран Я.В. Обоснование целесообразности выращивания энергетических плантаций ивы Матсуда (Salix matsudana Koidz.) на сельскохозяйственных землях

Уяснено, как Харьковщина может присоединиться к реальному решению проблемы энергосбережения и развития биоэнергетики в рамках создания плантаций энергетической ивы Матсуда. В ходе исследования показана экономическая эффективность использования энергетической ивы Матсуда для энергообеспечения Харьковщины, доказана перспектива выращивания, переработки и использования биоэнергетических культур в Харьковской обл.

Для реализации цели исследования выполнены следующие задачи: проанализированы научные подходы при изучении проблем энергосбережения и биоэнергетики; рассмотрены особенности природно-ресурсного потенциала Харьковщины; проведены возможные наблюдения за развитием и ростом ивы Матсуда; исследованы реальные потребности и возможности вырашивания в Харьковской обл. энергетической ивы как биоэнергетической культуры; предложены Хозы био кого поте не; исследованы проблемы и перспективы развития биоэнергетики в Харьковской обл.

Ключевые слова: энергетические плантации, ива Матсуда (Salix matsudana), сельскохозяйственные земли, энергосбережения, экономическая эффективность, биоэнергетические культуры, биоэнергетический потенциал.

Bulat A.G., Taran Ya.V. Justification of the Expediency for the Cultivation of Energy Plantations of Matsud Willows (Salix matsudana Koidz.) on Agricultural Land

Some opportunities for Kharkiv to join the real solution of the problem of energy conservation and the development of bioenergy in the framework of the Matsud willow energy plantations are figured out. During the studies, we have shown the economic efficiency of the use of energy Matsud willow for providing power to Kharkiv. Some prospects for its cultivation, processing and use of bioenergy crops in Kharkiv region are proved. To achieve the goa of our research we have carried out the following tasks: to analyze scientific approaches in the study of the problems of energy saving and bio-energy; considered particularly natural-resource potential of the Kharkiv region; to hold the ability to monitor the development and growth of willow Matsudany; to investigate the real needs and the possibility of growing in Kharkiv region energy willows as bioenergy crops; to offere the possibility of using energy potential of our region as an energy-saving in Kharkiv region, and in Ukraine; to examine problems and prospects of bioenergy development in Kharkiv region.

Keywords: energy plantations of Matsud willow (Salix matsudana), agricultural land, energy conservation, economic efficiency, bioenergy crops, bio-energy potential.

\section{УДК 504.05:628.58}

Доц. Н.М. Гринчишин, канд. с.-г. наук

Львівський ДУ БЖД

\section{ПРИЧИНИ ТА НАСЛІДКИ ВИТОКІВ НАФТИ І НАФТОПРОДУКТІВ НА}

\section{ТРУБОПРОВІДНОМУ ТРАНСПОРТІ У ЛЬВІВСЬКІЙ ОБЛАСТІ}

Досліджено екологічну проблему витоків нафти і нафтопродуктів на трубопровідному транспорті. Представлено характеристику надзвичайних ситуацій, пов'язаних витоками нафти i нафтопродуктів під час транспортування їх трубопровідним транспортом на території Львівської обл. за останні десять років. Розглянуто причини вито- ків та встановлено, що основна причина більшої половини їх виникнення - несанкціоноване втручання у трубопровід. Проаналізовано наслідки витоків і досліджено, що забруднення грунту є наслідком майже всіх витоків нафти і нафтопродуктів під час транспортування їх трубопровідним транспортом, а забруднення водних об'єктів відбувається лише в разі витоків нафтопродуктів з продуктопроводів

Ключові слова: нафта, нафтопродукт, трубопровідний транспорт, забруднення, грунт

Вступ. Постачання нафти та нафтопродуктів до багатьох галузей економіки здійснюється усіма можливими видами транспорту, але найвигіднішим за техніко-економічними показниками є трубопровідний транспорт, який набув найкращого розвитку. Незважаючи на те, що це найбільш екологобезпечний вид транспорту, він може чинити серйозний негативний вплив на навколишнє середовище, який пов'язаний з небезпекою виникнення аварій, що супроводжуються виливами нафти і нафтопродуктів.

Відносно невеликі виливи нафти і нафтопродуктів можуть мати наслідки тривалого характеру й спричинювати серйозні збитки [1]. Досить часто забруднення грунтів і поверхневих вод нафтою і продуктами її перероблення призводить до забруднення грунтових вод, що унеможливлює їх використання для пиття [2]. Нерідко виливи нафти і нафтопродуктів призводять до надзвичайних ситуацій, які є найбільш небезпечними за своїми екологічними наслідками [1].

Аналіз надзвичайних ситуацій, пов'язаних із виливами нафти і нафтопродуктів на території Краснодарського краю, які відбулися протягом 19942006 рр., показав, що основний "внесок" (майже 70 \%) належить магістральним і промисловим нафтопроводам [3]

Основними причинами виникнення аварійних виливів нафти і нафтопродуктів на трубопровідному транспорті є зношеність основних фондів та несанкціоновані втручання у цілісність трубопроводів $[4,5]$. Загрози довкіллю, які виникають під час експлуатації нафтопроводів, пов'язані з аварійними виливами нафти, особливо небезпечні, якщо вони супроводжуються потраплянням розлитої нафти у водні системи. А тому значну небезпеку для наземних екосистем становлять переходи трубопроводів через річки та озера [6].

Отже, екологічна безпека трубопровідного транспорту під час транспортування нафти та нафтопродуктів полягає у мінімізації негативного впливу на довкілля. Світовий досвід у вирішенні цієї проблеми свідчить про те, що діяльність із попередження виливів $є$ досить важливою, як і діяльність щодо їх ліквідації. Найчастіше облік ризиків розвитку аварійних ситуацій потенційними джерелами, контроль і нагляд за недопущенням розвитку подібних ситуацій $з$ боку держави, а отже, попередження можливих виливів нафти і нафтопродуктів стає набагато менш витратною справою, ніж ліквідація їх наслідків [7].

Отже, територіальне розміщення трубопровідного транспорту впливає на екологічний стан регіонів. 3 огляду на це, важливо та актуально проаналізувати причини і наслідки витоків нафти і нафтопродуктів зі системи трубопроводів на певній території з метою їх попередження.

Мета дослідження - проаналізувати основні причини та наслідки витоків нафти і нафтопродуктів під час транспортування їх трубопровідним транспортом на території Львівської обл. за останні десять років. 
Матеріали та методи. Інформаційною базою дослідження були матеріали до Національної доповіді України про стан навколишнього природного середовища по Львівській обл., а саме інформація про об'єкти кризового моніторингу довкілля, спостереження за якими проводить департамент 3 питань цивільного захисту Львівської обласної державної адміністрації.

Виклад основного матеріалу. Основними об'єктами трубопровідного транспорту, якими транспортується нафта і продукти ії перероблення на території Львівської обл., є система магістральних нафтопроводів "Дружба" [8] та продуктопровід ДП "ПрикарпатЗахідтранс" (протяжність 282 км на території області) [9]. За даними матеріалів досліджень [10], упродовж 2005-2014 pp. на території Львівської обл. сталося 27 надзвичайних ситуацій, пов'язаних із витоками нафти і нафтопродуктів під час транспортування їх трубопровідним транспортом. Коротку характеристику цих ситуацій подано в табл. 1.

Табл. 1. Характеристика надзвичайних ситуацій, пов'язаних із витоками нафти нафтопродуктів при транспортуванні їх трубопровідним транспортом на

\begin{tabular}{|c|c|c|c|c|}
\hline \begin{tabular}{|l|l|} 
№ \\
\end{tabular} & 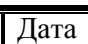 & Місце аварії & Опис ситуації & П Причина \\
\hline \begin{tabular}{|l|}
1 \\
\end{tabular} & $\begin{array}{l}29.06 . \\
2005\end{array}$ & $\begin{array}{l}\text { с. Жирівка } \\
\text { Пустомитівського р-ну }\end{array}$ & \begin{tabular}{|l} 
Витік з продуктопроводу \\
ДП "ПрикарпатЗахідтранс" \\
дизельного палива (приблизно 2 т)
\end{tabular} & $\begin{array}{l}\text { Несанкціоноване } \\
\text { втручання у } \\
\text { продуктопровід }\end{array}$ \\
\hline \begin{tabular}{|l|}
2 \\
\end{tabular} & $\begin{array}{l}16.07 . \\
2005\end{array}$ & $\begin{array}{l}\text { м. Стебник } \\
\text { Дрогобицького р-ну }\end{array}$ & $\begin{array}{l}\text { Витік з підземного продуктопро- } \\
\text { воду ТзОВ "Карпатнафтохім" ди- } \\
\text { зельного палива (приблизно 4 т) }\end{array}$ & $\begin{array}{l}\text { Несанкціоноване } \\
\text { втручання у } \\
\text { продуктопровід }\end{array}$ \\
\hline \begin{tabular}{|l|}
3 \\
\end{tabular} & $\begin{array}{l}17.07 . \\
2006\end{array}$ & $\begin{array}{l}\text { c. Унятичі } \\
\text { Дрогобицького р-ну }\end{array}$ & $\begin{array}{l}\text { Витік з продуктопроводу } \\
\text { ДП "ПрикарпатЗахідтранс" ди- } \\
\text { зельного палива (приблизно } 5 \text { т) }\end{array}$ & $\begin{array}{l}\text { Несанкціоноване } \\
\text { втручання у } \\
\text { продуктопровід }\end{array}$ \\
\hline \begin{tabular}{|l|}
4 \\
\end{tabular} & $\begin{array}{l}14.10 . \\
2006\end{array}$ & $\begin{array}{l}\text { с. Почаєвичі } \\
\text { Дрогобицького р-ну }\end{array}$ & $\begin{array}{l}\text { Витік з нафтопроводу ВАТ НПК } \\
\text { "Галичина" дизпалива } \\
\text { (приблизно 1,5 т) }\end{array}$ & $\begin{array}{l}\text { Несанкціоноване втру- } \\
\text { чання у продуктопро- } \\
\text { від }\end{array}$ \\
\hline \begin{tabular}{|l|}
5 \\
\end{tabular} & $\begin{array}{l}21.10 . \\
2006\end{array}$ & $\begin{array}{l}\text { мікрорайон "Млинки" } \\
\text { м. Дрогобича }\end{array}$ & $\begin{array}{l}\text { Витік з продуктопроводу "Дрого- } \\
\text { бич-Калуш" дизельного } \\
\text { палива (приблизно } 150 \text { л) }\end{array}$ & $\begin{array}{l}\text { Несанкціоноване } \\
\text { втручання у } \\
\text { продуктопровід }\end{array}$ \\
\hline \begin{tabular}{|l|l}
6 \\
\end{tabular} & $\begin{array}{l}16.11 . \\
2006\end{array}$ & $\begin{array}{l}\text { c. Задністря та Чуква } \\
\text { Самбірського р-ну }\end{array}$ & $\begin{array}{l}\text { Витік з продуктопроводу } \\
\text { ДП "ПрикарпатЗахідтранс" } \\
\text { дизпалива }\end{array}$ & $\begin{array}{l}\text { Несанкціоноване } \\
\text { втручання у } \\
\text { продуктопровід }\end{array}$ \\
\hline \begin{tabular}{|l|}
7 \\
\end{tabular} & $\begin{aligned} 22.01 . \\
2007\end{aligned}$ & \begin{tabular}{|l} 
поблизу с. Лішня \\
Дрогобицького р-ну
\end{tabular} & $\begin{array}{l}\text { Витік з нафтопроводу } \\
\text { ВАТ НПК "Галичина" } 1 \text { т нафти }\end{array}$ & $\begin{array}{l}\text { Пошкодження труби } \\
\text { через корозію }\end{array}$ \\
\hline 8 & $\begin{array}{l}21.03 . \\
2007\end{array}$ & $\begin{array}{l}\text { Поблизу с. Долобів } \\
\text { Самбірського р-ну }\end{array}$ & $\begin{array}{l}\text { Витік з продуктопроводу } \\
\text { ДП "ПрикарпатЗахідтранс" диз- } \\
\text { палива (приблизно } 150 \text { л) }\end{array}$ & $\begin{array}{l}\text { Несанкціоноване } \\
\text { втручання у } \\
\text { продуктопровід }\end{array}$ \\
\hline \begin{tabular}{|c|}
9 \\
\end{tabular} & $\begin{array}{c}05.04 . \\
2007\end{array}$ & \begin{tabular}{|l} 
поблизу с. Чайковичі \\
Самбірського р-ну
\end{tabular} & $\begin{array}{l}\text { Витік з продуктопроводу ДП } \\
\text { "Прикарпат-Західтранс" } \\
\text { дизельного палива }\end{array}$ & 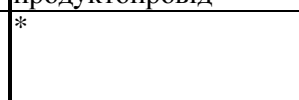 \\
\hline 10 & $\begin{array}{l}07.05 . \\
2007\end{array}$ & $\begin{array}{l}\text { поблизу с. Голосковичі } \\
\text { Бродівського р-ну }\end{array}$ & $\begin{array}{l}\text { Витік з нафтопроводу "Дружба" } \\
\text { сирої нафти понад } 2000 \text { л }\end{array}$ & $*$ \\
\hline \begin{tabular}{|l|}
11 \\
\end{tabular} & $\begin{array}{c}13.06 . \\
2007\end{array}$ & \begin{tabular}{|l|}
391 км ділянки першої \\
черги Мозир-Броди \\
нафтопроводу "Дружба"
\end{tabular} & $\begin{array}{l}\text { Витік з нафтопроводу "Дружба" } \\
\text { нафти (30 л) }\end{array}$ & $\begin{array}{l}\text { Проведення } \\
\text { ремонтних робіт на } \\
\text { нафтопроводі }\end{array}$ \\
\hline \begin{tabular}{|l|}
12 \\
\end{tabular} & $\begin{array}{l}01.11 . \\
2007\end{array}$ & $\begin{array}{l}\text { поблизу с. Дубляни } \\
\text { Самбірського р-ну }\end{array}$ & $\begin{array}{l}\text { Витік з продуктопроводу } \\
\text { ДП "ПрикарпатЗахідтранс" } \\
\text { дизельного палива (понад } 30 \text { л) }\end{array}$ & $\begin{array}{l}\text { Пошкодження труби } \\
\text { трактором під час } \\
\text { проведення польових } \\
\text { робіт }\end{array}$ \\
\hline
\end{tabular}

\begin{tabular}{|c|c|c|c|c|}
\hline 13 & $\begin{array}{l}19.01 . \\
2008\end{array}$ & $\begin{array}{l}\text { с. Ясениця-Замкова } \\
\text { Старосамбірського } \\
\text { p-ну }\end{array}$ & $\begin{array}{l}\text { Витік з продуктопроводу } \\
\text { ДП "ПрикарпатЗахідтранс" } \\
\text { дизельного палива }\end{array}$ & $\begin{array}{l}\text { Несанкціоноване } \\
\text { втручання у } \\
\text { продуктопровід }\end{array}$ \\
\hline 14 & $\begin{array}{l}15.03 . \\
2008\end{array}$ & $\begin{array}{l}\text { c. Яблуунівка } \\
\text { Бродівського р-ну }\end{array}$ & $\begin{array}{l}\text { Витік з нафтопроводу "Дружба" } \\
\text { нафти (приблизно } 1 \text { т) }\end{array}$ & $\begin{array}{l}\text { Несанкціоноване } \\
\text { втручання у } \\
\text { продуктопровід }\end{array}$ \\
\hline 15 & $\begin{array}{c}07.04 . \\
2008\end{array}$ & $\begin{array}{l}\text { с. Гніздичів } \\
\text { Жидачівського р-ну }\end{array}$ & $\begin{array}{l}\text { Витік з нафтопроводу "Дружба" } \\
\text { нафти (понад } 1600 \text { л) }\end{array}$ & $\begin{array}{l}\text { Несанкціоноване } \\
\text { втручання у } \\
\text { продуктопровід }\end{array}$ \\
\hline 16 & $\begin{array}{l}18.05 \\
2008\end{array}$ & $\begin{array}{l}\text { між с. Лучківці та } \\
\text { с. Ясенів } \\
\text { Бродівського р-ну }\end{array}$ & $\begin{array}{l}\text { Витік з продуктопроводу } \\
\text { ДП "ПрикарпатЗахідтранс" дизель- } \\
\text { ного палива (приблизно } 1000 \text { л) }\end{array}$ & $\begin{array}{l}\text { Несанкціоноване } \\
\text { втручання у } \\
\text { продуктопровід }\end{array}$ \\
\hline 17 & $\begin{array}{l}28.11 . \\
2008\end{array}$ & $\begin{array}{l}\text { c. Голосковичі } \\
\text { Бродівського р-ну }\end{array}$ & $\begin{array}{l}\text { Витік нафти з нафтопроводу } \\
\text { "Дружба" }\end{array}$ & $*$ \\
\hline 18 & $\begin{array}{l}11.12 . \\
2009\end{array}$ & $\begin{array}{l}\text { c. Сушиця Старосам- } \\
\text { бірського р-ну }\end{array}$ & $\begin{array}{l}\text { Витік з продуктопроводу ДП } \\
\text { "ПрикарпатЗахідтранс" дизельно- } \\
\text { го палива }\end{array}$ & $\begin{array}{l}\text { Несанкціоноване } \\
\text { втручання у } \\
\text { продуктопровід }\end{array}$ \\
\hline 19 & $\begin{array}{c}02.02 . \\
2011\end{array}$ & $\begin{array}{l}\text { с. Петричі } \\
\text { Буського р-ну }\end{array}$ & $\begin{array}{l}\text { Витік з продуктопроводу } \\
\text { ДП "ПрикарпатЗахідтранс" } \\
\text { дизельного палива }\end{array}$ & $\begin{array}{l}\text { Розгерметизація про- } \\
\text { дуктопроводу внаслі- } \\
\text { док корозії металу }\end{array}$ \\
\hline 20 & $\begin{array}{l}15.04 . \\
2011\end{array}$ & $\begin{array}{l}\text { с. Присліп } \\
\text { Турківського р-ну }\end{array}$ & $\begin{array}{l}\text { Витік з продуктопроводу ДП } \\
\text { "Прикарпат Західтранс" } \\
\text { дизельного палива }\end{array}$ & $\begin{array}{l}\text { Зловмисне пошкоджен- } \\
\text { ня продуктопроводу } \\
\text { невідомою особою }\end{array}$ \\
\hline 21 & $\begin{array}{l}21.05 . \\
2011\end{array}$ & $\begin{array}{l}\text { c. Чайковичі } \\
\text { Самбірського р-ну }\end{array}$ & $\begin{array}{l}\text { Витік з продуктопроводу } \\
\text { ДП "ПрикарпатЗахідтранс" } \\
\text { дизельного палива }\end{array}$ & $\begin{array}{l}\text { Несанкціоноване } \\
\text { втручання у } \\
\text { продуктопровід }\end{array}$ \\
\hline 22 & $\begin{array}{c}03.08 . \\
2011\end{array}$ & $\begin{array}{l}\text { с. Переможне } \\
\text { Городоцького р-ну }\end{array}$ & $\begin{array}{l}\text { Витік з продуктопроводу ДП } \\
\text { "ПрикарпатЗахідтранс" } \\
\text { дизельного палива }\end{array}$ & $\begin{array}{l}\text { Несанкціоноване } \\
\text { втручання у } \\
\text { продуктопровід }\end{array}$ \\
\hline 23 & $\begin{array}{c}12.04 . \\
12\end{array}$ & $\begin{array}{l}\text { с. Болехів Дрогобиць- } \\
\text { кого р-ну }\end{array}$ & $\begin{array}{l}\text { Витік з нафтопроводу "Жулин- } \\
\text { Дрогобич" нафти }\left(3 \text { м }^{3}\right)\end{array}$ & $\begin{array}{l}\text { Несанкціоноване } \\
\text { втручання у } \\
\text { продуктопровід }\end{array}$ \\
\hline 24 & $\begin{array}{l}05.11 . \\
2012\end{array}$ & $\begin{array}{l}\text { с. Модриця Дрогобиць- } \\
\text { кого р-ну }\end{array}$ & $\begin{array}{l}\text { Витік з продуктопроводу ДП } \\
\text { "ПрикарпатЗахідтранс" } \\
\text { дизельного палива }\end{array}$ & $x^{2}+2-2$ \\
\hline 25 & $\begin{array}{l}05.12 . \\
2012\end{array}$ & $\begin{array}{l}\text { поблизу с. Хватів Бусь- } \\
\text { кого р-ну на території } \\
\text { Бродівського р-ну }\end{array}$ & $\begin{array}{l}\text { Витік з продуктопроводу } \\
\text { ДП "ПрикарпатЗахідтранс" } \\
\text { дизпалива (приблизно } 40 \text { л) }\end{array}$ & $\begin{array}{l}\text { Несанкціоноване } \\
\text { втручання у } \\
\text { продуктопровід }\end{array}$ \\
\hline 26 & $\begin{array}{l}22.08 . \\
2014\end{array}$ & Дрогобицький р-н & $\begin{array}{l}\text { Витік з нафтопроводу } \\
\text { "Орів-Дрогобич" сирої нафти }\end{array}$ & $\begin{array}{l}\text { Несанкціоноване } \\
\text { втручання у } \\
\text { продуктопровід }\end{array}$ \\
\hline 27 & $\begin{array}{l}19.10 . \\
2014\end{array}$ & $\begin{array}{l}\text { с. Тухолька Сколівсь- } \\
\text { кого р-ну }\end{array}$ & $\begin{array}{l}\text { Витік з нафтопроводу } \\
\text { "Дружба" нафти }\end{array}$ & $\begin{array}{l}\text { Несанкціоноване } \\
\text { втручання у } \\
\text { продуктопровід }\end{array}$ \\
\hline
\end{tabular}

Примітка: * - інформація про причину витоку відсутня.

Аналізуючи місця витоків нафти і нафтопродуктів зі системи трубопроводів на території Львівської обл. за останні десять років можна побачити (див. табл. 1), що вони були в Пустомитівському, Дрогобицькому, Сколівському, Бродівському, Городоцькому, Самбірському, Старосамбірському, Буському та Турківському р-нах. Варто зазначити, що найбільше витоків (понад 25 \% від загальної кількості) за досліджуваний період відбулося на території Дрогобицького р-ну. Динаміку загальної кількості витоків нафти і нафтопродуктів на трубопровідному транспорті у Львівській обл. за останні десять років представлено на рис. 1

2. Екологія та довкілля 


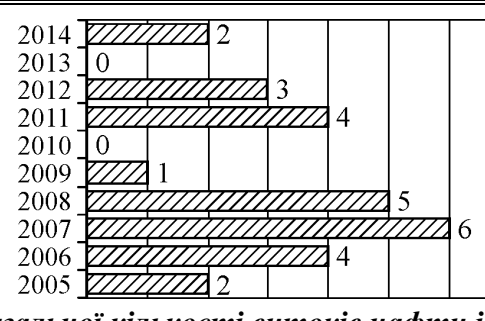

Рис. 1. Динаміка загальної кількості витоків нафти і нафтопродуктів на трубопровідному транспорті у Львівській обл. за останні десять років

3 рис. 1 спостерігається позитивна тенденція щодо зменшення вдвічі кількості витоків нафти і нафтопродуктів із системи трубопроводів на території Львівської обл. за останні п'ять років, порівняно 3 аналогічним періодом за 2005-2009 рр. Динаміка кількості витоків із різних трубопроводів (рис. 2) показує, що з нафтопродуктопроводів сталося 17 витоків, а 3 нафтопроводів - 10 , співвідношення між якими становить 63 і $37 \%$.

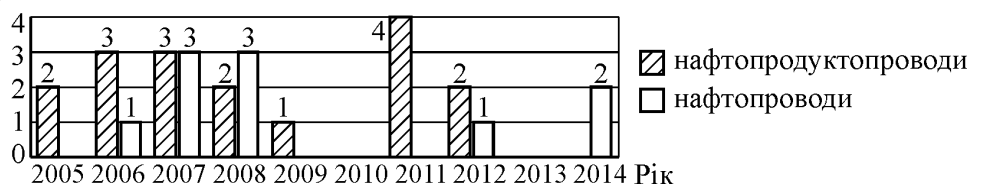

Рис. 2. Динаміка кількості витоків із нафтопроводів і нафтопродуктопроводіє у Львівській обл. протягом 2005-2014 pp.

До факторів, які спричинили витоки нафти і нафтопродуктів 3 лінійної частини трубопроводів, належать: корозія труб, несанкціоновані втручання, ремонтні роботи, зловмисні й незловмисні пошкодження (див. табл. 1). Співвідношення причин виникнення витоків нафти і нафтопродуктів зі системи трубопроводів (рис. 3) вказує, що причиною половини всіх витоків (66 \% від кількості) $\epsilon$ несанкціоноване втручання у цілісність трубопроводів.

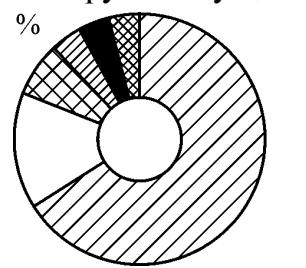

$$
\begin{aligned}
& \square \text { несанкціонована врізка; } 66 \\
& \square \text { причину не встановлено; } 15 \\
& \text { корозія труб; } 7 \\
& \text { ремонтні роботи; } 4 \\
& \text { пошкодження незловмисне; } 4 \\
& \text { пошкодження зловмисне; } 4
\end{aligned}
$$

Рис. 3. Співвідношення причин виникнення витоків нафти і нафтопродуктів із системи трубопроводів на території Львівської обл. протягом 2005-2014 рp.

Дослідження співвідношення кількості витоків з причини несанкціонованого втручання та іншими причинами, які відбулися на різних трубопроводах, показало, що внаслідок несанкціонованого втручання сталося $82 \%$ витоків 3 нафтопродуктопроводів і $60 \%$ - із нафтопроводів (рис. 4).

Отже, впродовж останніх десяти років система нафтопродуктопроводів на території Львівської обл. зазнала більш негативного впливу від зовнішнього людського чинника, порівняно зі системою нафтопроводів. Це можна пояснити ширшим практичним використанням нафтопродуктів, а також відсутністю або неналежним контролем системи продуктопроводів спеціальними підрозділами охорони. Узагальнену інформацію про наслідки витоків нафти і нафтопродуктів з різних систем трубопроводів на території Львівської обл. за останні десять років на основі матеріалів досліджень [10] представлено в табл. 2.

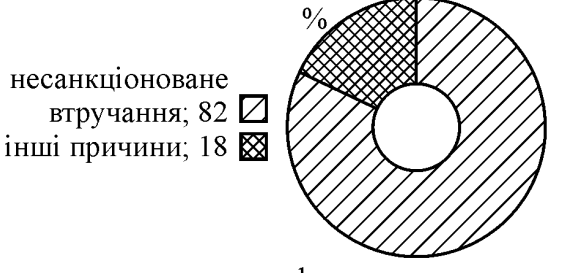

нафтопродуктопроводи

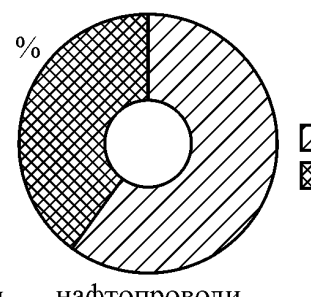

нафтопроводи несанкціоноване

втручання; 60 інші причини; 40
Рис. 4. Співвідношення кількості витоків із причини несанкціонованого втручання та іншими причинам, які сталися на різних трубопроводах

$$
\text { y Львівської обл. протягом 2005-2014 pр. }
$$

Результати аналізу наслідків витоків нафти і нафтопродуктів із системи трубопроводів (див. табл. 2) свідчать, шо майже всі вони призводять до забруднення грунтів, тоді як забруднення водних об'єктів відбувається внаслідок витоків із нафтопродуктопроводів. Однак порівняти наслідки витоків неможливо, через відсутність інформації про наслідки витоків або неповну інформацію про них [10]. Так, у випадках, пов'язаних із забрудненням грунту. не скрізь вказано площу забруднення, а інформації про глибину проникнення нафти і нафтопродуктів у грунт взагалі немає.

Щодо випадків, пов'язаних із забрудненням поверхневих водних об'єктів, не всюди зазначено інформацію про площу забруднення водної поверхні (див. табл. 2). Саме ця інформація необхідна для розрахунку економічного збитку, який може слугувати універсальним показником для порівняння наслідків забруднення. А тому надалі департаменту з питань цивільного захисту Львівської обласної державної адміністрації необхідно повніше інформувати про наслідки забруднення компонентів природного середовища від об'єктів кризового моніторингу довкілля.

Треба також зазначити, шо кожна ситуація, пов'язана з витоками нафти і нафтопродуктів із системи трубопроводів, погіршує загальний екологічний стан територій та потребує виконання робіт з ліквідації наслідків забруднення. А тому зазначене вище вимагає забезпечення посиленого контролю і нагляду з боку контролюючих органів для попередження і виявлення можливих аварійних ситуацій та спроб несанкціонованого доступу до трубопроводів.

Висновки. На території Львівської обл. упродовж 2005-2014 рр. сталося 27 надзвичайних ситуацій, пов'язаних із витоками нафти і нафтопродуктів під час транспортування їх трубопровідним транспортом. Найбільше витоків відбулося на території Дрогобицького р-ну.

Співвідношення витоків у системах нафтопроводів і продуктопроводів становить 37 і $63 \%$. Більша половина усіх витоків нафти і нафтопродуктів відбулася через несанкціоноване втручання у цілісність трубопроводів. Забруднення грунту - основний наслідок витоків нафти і нафтопродуктів зі системи тру- 
бопроводів, тоді як забруднення водних об'єктів відбувається внаслідок витоків 3 нафтопродуктопроводів.

Табл. 2. Наслідки витоків нафти і нафтопродуктів з різних систем трубопроводів на території Львівської обл. за останні десять років

\begin{tabular}{|c|c|c|c|c|c|}
\hline \multirow[b]{2}{*}{ № } & \multirow[b]{2}{*}{$\begin{array}{c}\text { Дата } \\
\text { витоку }\end{array}$} & \multirow{2}{*}{$\begin{array}{c}\text { Приб- } \\
\text { лизна } \\
\text { кіль- } \\
\text { кість } \\
\text { витоку }\end{array}$} & \multicolumn{3}{|c|}{ Наслідки витоку } \\
\hline & & & $\begin{array}{c}\text { забруднення } \\
\text { грунту (інформа- } \\
\text { ція про площу } \\
\text { забруднення) }\end{array}$ & \begin{tabular}{|c|} 
забруднення \\
меліоративного каналу \\
(інформація про від- \\
стань забруднення) \\
\end{tabular} & $\begin{array}{c}\text { забруднення } \\
\text { водних об'єктів }\end{array}$ \\
\hline \multicolumn{6}{|c|}{ нафтопродуктопроводи } \\
\hline 1 & 29.06.2005 & $2 \mathrm{~T}$ & $+\left(20 \mathrm{M}^{2}\right)$ & & $\begin{array}{c}\text { p. Зубра, яка впадає } \\
\text { у р. Дністер }\end{array}$ \\
\hline 2 & 16.07.2005 & $4 \mathrm{~T}$ & & & $\begin{array}{l}\text { лісове озеро розміром } 2500 \mathrm{~m}^{2} \\
\text { за межами охоронної зони }\end{array}$ \\
\hline 3 & 17.07 .2006 & $5 \mathrm{~T}$ & $+\left(100 \mathrm{M}^{2}\right)$ & & p. Бар \\
\hline 4 & 21.10 .2006 & 150 л & + & & \\
\hline 5 & 16.11.2006 & & & & $\begin{array}{c}\text { p. Чукв'янка, яка впадає } \\
\text { у р. Дністер }\end{array}$ \\
\hline 6 & 21.03 .2007 & & + & + & р. Дністер \\
\hline 7 & 05.04 .2007 & & & $+(150 \mathrm{M})$ & \\
\hline 8 & 01.11 .2007 & & + & & \\
\hline 9 & 19.01.2008 & & + & & $\begin{array}{c}\text { струмок у с. Ясениця-Замкова } \\
\text { Старосамбірського р-ну }\end{array}$ \\
\hline 10 & 18.05 .2008 & 1000 л & $+\left(163 \mathrm{M}^{2}\right)$ & & \\
\hline 11 & 11.12 .2009 & & $+\left(18 \mathrm{~m}^{2}\right)$ & & \\
\hline 12 & 02.02 .2011 & & $+\left(250 \mathrm{M}^{2}\right)$ & & \\
\hline 13 & 15.04 .2011 & & + & & \\
\hline 14 & 21.05 .2011 & & $+\left(20 \mathrm{M}^{2}\right)$ & & \\
\hline 15 & 03.08 .2011 & & $+\left(15 \mathrm{M}^{2}\right)$ & & p. Струга та р. Верещиця \\
\hline 16 & 05.11 .2012 & & $+\left(4 \mathrm{M}^{2}\right)$ & & \\
\hline 17 & 05.12 .2012 & 40 л & $+\left(50 \mathrm{M}^{2}\right)$ & & \\
\hline \multicolumn{6}{|c|}{ нафтопроводи } \\
\hline 1 & 14.10 .2006 & $1,5 \mathrm{~T}$ & + & $+(380 \mathrm{M})$ & \\
\hline 2 & 22.01 .2007 & $1 \mathrm{~T}$ & & $+(120 \mathrm{M})$ & \\
\hline 3 & 07.05 .2007 & 2000 л & $+\left(120 \mathrm{M}^{2}\right)$ & & \\
\hline 4 & 13.06 .2007 & 30 л & $+\left(4 \mathrm{M}^{2}\right)$ & & \\
\hline 5 & 15.03 .2008 & $1 \mathrm{~T}$ & $+\left(258 \mathrm{M}^{2}\right)$ & & \\
\hline 6 & 07.04 .2008 & 1600 л & $+\left(200 \mathrm{M}^{2}\right)$ & & \\
\hline 7 & 28.11 .2008 & & $+\left(5 \mathrm{M}^{2}\right)$ & & \\
\hline 8 & 12.04 .2012 & $3 \mathrm{~m}^{3}$ & + & & \\
\hline 9 & 22.08 .2014 & & + & & \\
\hline 10 & 19.10 .2014 & & $+\left(50 \mathrm{M}^{2}\right)$ & & \\
\hline
\end{tabular}

Кожна ситуація, спричинена витоками нафти і нафтопродуктів із системи трубопроводів, погіршує загальний екологічний стан територій та вимагає виконання робіт із ліквідації наслідків забруднення, а тому попередження таких ситуацій потребує посиленого контролю і нагляду за трасами трубопроводів 3 боку контролюючих органів.

\section{Література}

1. Владимиров В.А. Аварийные и другие несанкционированные разливы нефти / В.А. Владимиров, П.Ю. Дубнов // Стратегия гражданской защиты: проблемы и исследования. - 2013. - № 1. [Электронный pecypc]. - Доступный c http://www.cyberleninka.ru.
2. Карабин В.В. Щодо динаміки забруднення грунтових вод Передкарпаття у зоні техногенезу родовищ нафти / Василь Карабин, Володимир Колодій, Олександр Яронтовський, Юлія Козак, Оксана Карабин // Праці наукового товариства імені Шевченка. - Т. ХІХ. Геологічний збірник, 2007. - С. 182-190.

3. Пикалов М.А. Анализ чрезвычайных ситуаций, обусловленных разливами нефти и нефтепродуктов, произошедших с 1994 по 2006 гг., и выполняемой работы АСФ (Н) по ликвидации ЧС (Н) и реабилитации территорий и акваторий, загрязненных нефтью и нефтепродуктами / М.А. Пикалов, А.М. Баринов // Стратегия гражданской зашиты: проблемы и исследования : сб. М.А. П .

4. Василюк В.М. Підвищення надійності роботи магістральних нафтопроводів ВАТ "Укртранснафта" / В.М. Василюк // Вісник національної газової спілки України : зб. наук. праць. 2004. № 4 - - C $11-14$.

5. Моніторинг та оцінювання екологічних ризиків техногенного походження. Аналітична доповідь / С. Іванюта. - К. : Вид-во НІСД, 2012. - 52 с.

6. Липский В.К. Основы охраны водных обьектов от аварийных сбросов нефтяных загрязнителей / В.К. Липский, Л.М. Спириденок, Д.М. Комаровский, А.А. Гвоздева // Материалы IV Международного водного форума (г. Минск, 12-13 октября 2010 г.)- Минск : Изд-во "Минсктиппроект", 2011. - С. 185-187.

7. Рыбаков С.Н. Разливы, что хорошего / С.Н. Рыбаков, С.Д. Майер, А.Г. Тарасов // Центр экологии ТЭК : сб. науч. тр. [Электронный ресурс]. - Доступный с http://www.cetek.ru/informaciya-i-analitika.

8. Філія "Магістральні нафтопроводи "Дружба". [Електронний ресурс]. - Доступний 3 http://www.naftogaz.lviv.ua/utn.htm.

9. ДП "ПрикарпатЗахідтранс". [Електронний ресурс]. - Доступний http://www.dppzt.com.ua.

10. Регіональна доповідь про стан навколишнього прир. середовиша у Львівській області в 2005 р., (2006-2014рр.) : матер. до Національної доповіді про стан НПС по Львівській області. [Електронний ресурс]. - Доступний 3 http://www.ekologia.lviv.ua/index.php.

Гринчишин Н.Н. Причины и последствия истоков нефти и нефтепродуктов на трубопроводном транспорте во Львовской области

Исследована экологическая проблема истоков нефти и нефтепродуктов на трубопроводном транспорте. Представлена характеристика чрезвычайных ситуаций, связанных с истоками нефти и нефтепродуктов при транспортировке их трубопроводным транспортом на территории Львовской обл. за последние десять лет. Рассмотрены причины истоков и установлено, что основная причина большей половины их возникновения - несанкционированное вмешательство в трубопроводы. Проанализированы последствия истоков и исследовано, что загрязнение почвы является следствием почти всех истоков нефти и нефтепродуктов при транспортировке их трубопроводным транспортом, а загрязнение водных объектов происходит лишь при истоках нефтепродуктов из продуктопроводов. нение.

Ключевые слова: нефть, нефтепродукт, трубопроводный транспорт, исток, загряз-

Grynchyshyn N.N. Causes and Consequences of Oil Leaks and Oil Products on Pipeline Transport in L'viv Region

The environmental problem of oil leaks and oil products on pipeline transport is studied. Some characteristics of emergency situations connected with oil leaks and oil products during transportation of pipelines in the L'viv region in the last ten years are presented. Some causes of leaks are considered. The main cause of more than half their appearance as unauthorized intervention in pipeline is determined. The consequences of leaks are analysed. Soil contamination is proved to be the result of almost all oil leaks and oil products during transportation of pipelines and pollution of water objects is only with the origins of petroleum product pipelines.

Keywords: oil, petroleum, pipeline transport, contamination, soil. 